\title{
Nosocomial Infections and Agents Determined by Consultations in Intensive Care Unit
}

\author{
Yoğun Bakım Ünitesinde Konsültasyonlarla Belirlenen Hastane İnfeksiyonları ve Etkenleri \\ Seyit Ali BÜYÜKTUNA, Özge TURHAN, Melike CENGİZ, ${ }^{1}$ Atilla RAMAZANOĞLU, ${ }^{1}$ Ata Nevzat YALÇIN \\ Departments of Infectious Diseases and Clinical Microbiology, ${ }^{1}$ Anesthesiology and Reanimation, \\ Medical Faculty of Akdeniz University, Antalya
}

Submitted / Başvuru tarihi: 04.11.2008 Accepted / Kabul tarihi: 09.12.2008

Objectives: We investigated nosocomial infections diagnosed via consultations with the Department of Infectious Diseases and Clinical Microbiology at Reanimation I-II intensive care units.

Patients and Methods: Of 3750 patients hospitalized at Reanimation I-II intensive care units, 1221 patients were followed up via consultations with the Department of Infectious Diseases and Clinical Microbiology. Additionally, main diseases that require intensive care, other concomitant diseases, demographical data, hospital stays and isolated microorganisms were evaluated.

Results: Seven hundred and fifty-six patients $(61.9 \%)$ were diagnosed with nosocomial infections according to the criteria of Centers for Disease Control and Prevention. Among these infections, nosocomial pneumonia took the first place. As infectious agent, Pseudomonas spp. (19.7\%) took the first place, followed by Acinetobacter spp. (17.3\%) and Staphylococcus spp. (16.7\%).

Conclusion: Nosocomial infections are common at intensive care units. Besides infection control precautions, consultations with Infectious Diseases are also important in quick identification and treatment of these infections.

Key words: Intensive care units; infectious diseases; consultation.
Amaç: Reanimasyon I-II Yoğun Bakım Ünitelerinde, İnfeksiyon Hastalıkları ve Klinik Mikrobiyoloji Anabilim Dalı konsültasyonlarıyla tanı konulan nozokomiyal infeksiyonlar incelendi.

Hastalar ve Yöntemler: Yoğun bakım ünitelerinde yatan 3750 hastanın 1221'i İnfeksiyon Hastalıkları ve Klinik Mikrobiyoloji Anabilim Dalı konsültasyonlarıyla izlendi. Ayrıca yoğun bakıma yatış gerektiren primer ve diğer eşlik eden hastalıklar, demografik veriler, hastanede kalış ve izole edilen mikroorganizmalar da bu çalışmada değerlendirildi.

Bulgular: Centers for Disease Control and Prevention kriterlerine göre 756 hasta (\%61.9) nozokomiyal infeksiyon tanısı aldı. Bu infeksiyonlar arasında nozokomiyal pnömoni ilk sırada yer aldı. İnfeksiyon etkenleri olarak ilk sırada yer alan Pseudomonas spp.'i (\%19.7), Acinetobacter spp. (\%17.3) ve Staphylococcus spp. (\%16.7) takip etti.

Sonuç: Nozokomiyal infeksiyonlarla yoğun bakımlarda sık karşılaşılmaktadır. Bu infeksiyonlarda İnfeksiyon Hastalıkları konsültasyonları infeksiyon kontrolün yanısıra doğru ve hızlı tanı ve tedavide önem arz etmektedir.

Anahtar sözcükler: Yoğun bakım ünitesi; infeksiyon hastalıkları; konsültasyon.

Presented at the 3rd National Symposium of Critical Care Infections, June 21-24, 2007, Trabzon, Turkey (3. Ulusal Yoğun Bakım Infeksiyonları Sempozyumu'nda sunulmuştur, 21-24 Haziran 2007, Trabzon).

Correspondence (illetişim adresi): Dr. Özge Turhan. Akdeniz Üniversitesi Tıp Fakültesi Infeksiyon Hastalıkları ve Klinik Mikrobiyoloji Anabilim Dalı, 07070 Antalya. Tel: 0242 - 2496716 Fax (Faks): 0242 - 2274490 e-mail (e-posta): ozgeturhan@akdeniz.edu.tr

(c) Trakya Üniversitesi Tıp Fakültesi Dergisi. Ekin Tıbbi Yayıncıık tarafından basılmıştır. Her hakkı sakıııı.

(c) Medical Journal of Trakya University. Published by Ekin Medical Publishing. All rights reserved. 
Patients at intensive care units (ICU) make up only $5-10 \%$ of all inpatients. They are important units for nosocomial infections. About $25 \%$ of all nosocomial infections and $45-50 \%$ of all nosocomial pneumonia and bacteremia take place at these units. Agents of nosocomial infections at ICUs may differ among hospitals, even among different ICUs of the same hospital. The most well-known characteristics of these infections are resistant pathogens often to play role at the infection and the difficulty to treat the infections. The facts that underlying diseases of the patients at these units are serious and higher probability for patients to encounter resistant microorganisms cause the infections to result in serious mortality and morbidity. Hospital stay gets longer due to these infections and important financial detriments develop. For the optimization of antibiotic treatment at ICU infections, it is important to profile the agent according to body parts and to follow the antibiotic resistance patterns of these agents. ${ }^{[1-3]}$

Need to control resistance at these microorganisms and to use antibiotics rationally has seriously increased the share of consultations among duties performed by Infectious Diseases and Clinical Microbiology (IDCM) specialists. ${ }^{[4]}$

In this study, we aimed to investigate nosocomial infections diagnosed with IDCM Department's consultations, at Reanimation I-II ICUs.

\section{PATIENTS AND METHODS}

Of 3750 patients hospitalized at Reanimation I-II ICUs between April 1, 2003 and December 31, 2006, 1221 patients were followed up via consultations with tha Department of Infectious Diseases and Clinical Microbiology. Seven hundred and fifty-six patients $(61.9 \%)$ who were diagnosed with nosocomial infections according to the criteria of Centers for Disease Control and Prevention (www.cdc.gov/ncidod/dhqp) were investigated retrospectively.

Our university hospital is a regional reference hospital made up of three blocks and it has a capacity of 700 hospital beds. There are two reanimation units with a total of 23 beds. Except newborns and postoperative cardiac surgery patients, patients at all age groups from surgical and internal departments are followed up here and all modern intensive care applications are performed. The Department of Infectious Diseases and Clinical Microbiology serves since 1982.

Infectious Diseases consultations requested from the reanimation unit were followed regularly by IDCM residents accompanied by IDCM teaching staff since April 2003. The follow-up card has been arranged for every patient evaluated. After information about the patient is recorded on the card, microbiological followup of samples derived from the patients are noted down. Antibiotic choice is determined daily at teaching staffaccompanied visits, according to antibiotic sensitivity of producing microorganisms.

In this study, main diseases of patients at admission to ICU, other concomitant diseases, demographical data, hospital stays, isolated microorganisms and nosocomial infections were recorded daily to follow-up cards and data were transferred to SPSS 10.0 software and evaluated.

\section{RESULTS}

Of 756 patients included in the study, $508(67.2 \%)$ were male and $248(32.8 \%)$ were female. Mean age of the patients were $48.4 \pm 21.4$ years and mean stay at ICU was $26.5 \pm 23.3$ days. Total inpatients at ICUs and patients who acquired infections according to years were summarized at Table 1, primary diseases causing the need for administration to ICUs were summarized at Table 2.

It was detected that, of 1221 patients who were consulted, 756 patients developed 1855 nosocomial infections. Among these infections, nosocomial pneumonia took the first place (Table 3). As infection agent, Pseudomonas spp. took the first place, followed by Acinetobacter spp. and Staphylococcus spp. (Table 4).

The first five primary reasons of administration to ICUs for patients who have been consulted with Infectious Diseases were trauma $(32.8 \%)$, cerebrovascular event $(20.7 \%)$, malignancy $(11.3 \%)$, postoperative follow-up $(4.7 \%)$, and intra-abdominal abscess $(3.8 \%)$. During the long ICU stay of these patients, various invasive methods and wide-spectrum antibiotics have been used.

Table 1. Total number of inpatients at ICUs and patients who acquired infections, according to years

\begin{tabular}{lcccc}
\hline Year & Number of inpatients & $\begin{array}{c}\text { Number of } \\
\text { follow-up patients }\end{array}$ & $\begin{array}{c}\text { Number of patients } \\
\text { who acquired infections }\end{array}$ & $\begin{array}{c}\text { Total number of } \\
\text { infections }\end{array}$ \\
\hline 2003 (April-December) & 688 & 151 & 144 & 428 \\
2004 & 1004 & 409 & 207 & 436 \\
2005 & 1076 & 387 & 216 & 531 \\
2006 & 982 & 274 & 189 & 460 \\
Total & 3750 & 1221 & 756 & 1855 \\
\hline
\end{tabular}


Nosocomial Infections and Agents Determined by Consultations in Intensive Care Unit

Table 2. Primary diseases of the patients causing the need for administration to ICUs

\begin{tabular}{|c|c|c|c|c|c|}
\hline Reason of administration & $\mathrm{n}$ & $\%$ & Reason of administration & $\mathrm{n}$ & $\%$ \\
\hline Trauma & 248 & 32.8 & Injury with knife & 4 & 0.52 \\
\hline Cerebrovascular event & 157 & 20.76 & $\begin{array}{c}\text { HELLP (Hemolysis, } \\
\text { elevated liver enzyme concentrations, } \\
\text { low platelet counts) }\end{array}$ & 4 & 0.52 \\
\hline Malignancy & 86 & 11.37 & Encephalitis & 4 & 0.52 \\
\hline Postoperative & 36 & 4.76 & Tetanus & 3 & 0.39 \\
\hline Intra-abdominal abscess & 29 & 3.83 & Fournier's gangrene & 3 & 0.39 \\
\hline Chronic obstructive pulmonary disease & 27 & 3.57 & Gastrointestinal system bleeding & 3 & 0.39 \\
\hline Burns & 23 & 3.04 & Idiopathic pulmonary fibrosis & 2 & 0.26 \\
\hline Sepsis & 22 & 2.91 & Diabetic ketoacidosis & 2 & 0.26 \\
\hline Respiratory failure & 20 & 2.64 & Amyotrophic lateral sclerosis & 2 & 0.26 \\
\hline Intoxication & 13 & 1.71 & Rheumatoid arthritis & 1 & 0.13 \\
\hline Congestive heart failure & 12 & 1.58 & Chronic renal failure & 1 & 0.13 \\
\hline Pneumonia & 10 & 1.32 & Cholangitis & 1 & 0.13 \\
\hline Meningitis & 7 & 0.92 & Tubo-ovarian abscess & 1 & 0.13 \\
\hline Gunshot injury & 7 & 0.92 & Interstitial pulmonary disease & 1 & 0.13 \\
\hline Suffocation with water & 6 & 0.79 & Peritonitis & 1 & 0.13 \\
\hline Electricity shock & 6 & 0.79 & Cirrhosis of liver & 1 & 0.13 \\
\hline Cardiac arrest & 5 & 0.66 & Anorexia nervosa & 1 & 0.13 \\
\hline Pancreatitis & 4 & 0.52 & Pulmonary thromboembolism & 1 & 0.13 \\
\hline
\end{tabular}

\section{DISCUSSION}

Patients at ICUs make up a patient group who need invasive life support, in frequent contact with the healthcare staff, with a high probability of infection with antibioticresistant bacteria. ${ }^{[5]}$ The knowledge of local antibiotic resistance patterns of infectious diseases which cause important morbidity and mortality at ICU is as important as to diagnose, in point of determining treatment options. Recently, with new and wide-spectrum antibiotics entering the market, inappropriate antibiotics use has increased. As a result, an increase in the frequency of microorganisms causing resistant infections has been observed. In order to control the use of antimicrobial agents and resistance development, most hospital managements need IDCM specialists. ${ }^{[2,4,6-8]}$ Less usage of wide-spectrum antibiotics, fast switch to oral treatment and multidisciplinary approach by Infectious Diseases specialists cause a decline at antibiotic-resistant infections. Akalın et al. ${ }^{[9]}$ have observed that after continuous and systematic consultations with Infectious Diseases and rational antibiotics applications, sensitivity patterns of pathogens causing ICU infections were revealed.

Previous studies point out that Infectious Diseases consultations have been demanded for $40 \%$ of ICU patients. In our study, the rate of consultation demand for Reanimation I and II ICU patients was $32.6 \%$. By the help of Infectious Diseases consultations, antibiotics expenses and resistance development rates decrease, and morbidity and mortality rates stay lower. ${ }^{[4]}$

The most frequent infections acquired at the ICUs are pneumonia, urinary tract infections (UTI), bloodstream infections (BSI) and surgical site infections (SSI). According to the results of the European Prevalence of Infection in Intensive Care (EPIC); pneumonia takes the first rank with $46.9 \%$, UTI have the rate of $17.6 \%$ and BSI have the rate of $12 \% .{ }^{[5,10]}$ In a study performed by Erbay et al. ${ }^{[11]}$ in 2003 at Pamukkale University Medicine

Table 3. Distribution of infections according to years and infection areas

\begin{tabular}{|c|c|c|c|c|c|c|c|c|}
\hline \multirow[t]{2}{*}{ Year } & \multicolumn{2}{|c|}{ Urinary tract infections } & \multicolumn{2}{|c|}{ Bloodstream infections } & \multicolumn{2}{|c|}{ Pneumonia } & \multicolumn{2}{|c|}{ Surgical site infections } \\
\hline & $\mathrm{n}$ & $\%$ & $\mathrm{n}$ & $\%$ & $\mathrm{n}$ & $\%$ & $\mathrm{n}$ & $\%$ \\
\hline 2003 (April-December) & 91 & 21.3 & 101 & 23.6 & 173 & 40.4 & 63 & 14.7 \\
\hline 2004 & 108 & 24.7 & 96 & 22 & 176 & 40.4 & 56 & 12.9 \\
\hline 2005 & 109 & 20.5 & 136 & 25.6 & 202 & 38 & 84 & 15.8 \\
\hline Total & 401 & 21.6 & 465 & 25 & 710 & 38.3 & 279 & 15 \\
\hline
\end{tabular}


Table 4. Distribution of microorganisms according to years

\begin{tabular}{|c|c|c|c|c|c|c|c|c|}
\hline \multirow[t]{2}{*}{ Agent } & \multicolumn{2}{|c|}{2003 (April-December) } & \multicolumn{2}{|c|}{2004} & \multicolumn{2}{|c|}{2005} & \multicolumn{2}{|c|}{2006} \\
\hline & $\mathrm{n}$ & $\%$ & $\mathrm{n}$ & $\%$ & $\mathrm{n}$ & $\%$ & $\mathrm{n}$ & $\%$ \\
\hline Pseudomonas spp. & 106 & 20.8 & 97 & 20.6 & 119 & 19 & 101 & 18.6 \\
\hline Acinetobacter spp. & 96 & 19.4 & 84 & 17.8 & 114 & 18.2 & 75 & 13.8 \\
\hline Candida spp. & 48 & 9.4 & 70 & 14.8 & 62 & 9.9 & 48 & 8.8 \\
\hline E. coli & 17 & 3.3 & 27 & 5.7 & 41 & 6.5 & 38 & 7 \\
\hline Enterococcus spp. & 30 & 5.9 & 37 & 7.8 & 51 & 8.1 & 55 & 10.2 \\
\hline Klebsiella spp. & 45 & 8.8 & 43 & 9.1 & 54 & 8.6 & 57 & 10.5 \\
\hline MSSA & 37 & 7.3 & 27 & 5.7 & 34 & 5.4 & 33 & 6 \\
\hline MRSA & 37 & 7.3 & 18 & 3.8 & 36 & 5.7 & 16 & 2.9 \\
\hline MRCNS & 30 & 5.9 & 18 & 3.8 & 40 & 6.4 & 36 & 6.6 \\
\hline Enterobacter spp. & 24 & 4.7 & 17 & 3.6 & 25 & 3.9 & 31 & 5.7 \\
\hline Other & 36 & 7 & 34 & 7.2 & 50 & 7.9 & 51 & 9.4 \\
\hline Total & 509 & & 472 & & 626 & & 541 & \\
\hline
\end{tabular}

Faculty, the rate of pneumonia was found as $40.9 \%$, BSI $30.2 \%$, UTI $23.6 \%$ and SSI $15.3 \%$.

When the results of the consultations were evaluated, it was observed that, taking the occurrence areas of all the nosocomial infections at ICU patients into account, nosocomial pneumonias took the first place with a rate of $38.6 \%$. Pneumonias were followed by BSI with a rate of $25 \%$, UTI with a rate of $21.6 \%$ and SSI with a rate of $15 \%$. When frequency rates of nosocomial infections in our references were evaluated, it was observed that at different centers, bloodstream infections or urinary tract infections differed for the second place after pneumonias.

Microorganisms causing the infections at ICUs and resistance patterns may differ among hospitals and among ICUs at the same hospital with different purposes. In the past years, Gram negative bacteria were more frequent as infection agents but recently an increase in the frequency of Gram positive bacteria has been reported. ${ }^{[12]}$ Namiduru et al. ${ }^{[13]}$ reported that Gram positive bacteria were isolated with a rate of $31.5 \%$ and Gram negative bacteria with a rate of $68.4 \%$. Palabıyıkoğlu et al. ${ }^{[14]}$ reported that, for nosocomial infections developing at ICUs, microorganims isolated were Gram negative with a rate of $63.9 \%$, Gram positive with $28.5 \%$ and Candida spp. with $7.6 \%$. Considering the frequency of bacteria isolated at ICUs, $P$. aeruginosa takes the first place among Gram negative bacteriae, where $S$. aureus and Coagulase Negative Staphylococci (CNS) are frequent among Gram positive bacteria. ${ }^{[14,15]}$ In a study by Orrett, ${ }^{[16]}$ the frequency of isolated Gram negative bacteria was reported as P. aeruginosa $(36.6 \%)$, K. pneumoniae $(20.6 \%)$, Enterobacter spp. $(16.8 \%)$. The frequency of isolated Grampositive bacteria was determined as $S$. aureus (41.8\%), CNS (30.9\%), Enterococcus spp. (20\%).

Table 5. Distribution of microorganisms according to infection areas

\begin{tabular}{|c|c|c|c|c|c|c|c|c|}
\hline \multirow[t]{2}{*}{ Agent } & \multicolumn{2}{|c|}{$\begin{array}{l}\text { Urinary tract } \\
\text { infections }\end{array}$} & \multicolumn{2}{|c|}{$\begin{array}{l}\text { Bloodstream } \\
\text { infections }\end{array}$} & \multicolumn{2}{|c|}{$\begin{array}{l}\text { Surgical site } \\
\text { infections }\end{array}$} & \multicolumn{2}{|c|}{ Pneumonia } \\
\hline & $\mathrm{n}$ & $\%$ & $\mathrm{n}$ & $\%$ & $\mathrm{n}$ & $\%$ & $\mathrm{n}$ & $\%$ \\
\hline Pseudomonas spp. & 106 & 20.8 & 97 & 20.6 & 119 & 19 & 101 & 18.6 \\
\hline Acinetobacter spp. & 96 & 19.4 & 84 & 17.8 & 114 & 18.2 & 75 & 13.8 \\
\hline Candida spp. & 48 & 9.4 & 70 & 14.8 & 62 & 9.9 & 48 & 8.8 \\
\hline E. coli & 17 & 3.3 & 27 & 5.7 & 41 & 6.5 & 38 & 7 \\
\hline Enterococcus spp. & 30 & 5.9 & 37 & 7.8 & 51 & 8.1 & 55 & 10.2 \\
\hline Klebsiella spp. & 45 & 8.8 & 43 & 9.1 & 54 & 8.6 & 57 & 10.5 \\
\hline MSSA & 37 & 7.3 & 27 & 5.7 & 34 & 5.4 & 33 & 6 \\
\hline MRSA & 37 & 7.3 & 18 & 3.8 & 36 & 5.7 & 16 & 2.9 \\
\hline MRCNS & 30 & 5.9 & 18 & 3.8 & 40 & 6.4 & 36 & 6.6 \\
\hline Enterobacter spp. & 24 & 4.7 & 17 & 3.6 & 25 & 3.9 & 31 & 5.7 \\
\hline Other & 36 & 7 & 34 & 7.2 & 50 & 7.9 & 51 & 9.4 \\
\hline Total & 509 & & 472 & & 626 & & 541 & \\
\hline
\end{tabular}


According to our consultation evaluations, Gram negative bacteria were isolated with a rate of $64.5 \%$, Gram positive with $24.7 \%$ and Candida spp. with $10.7 \%$. Among the most isolated agents Pseudomonas spp. took the first place with a rate of $19.7 \%$, followed by Acinetobacter spp. with $17.3 \%$, Staphylococcus spp. with $16.7 \%$, Candida spp. with $10.7 \%$, Klebsiella spp. with $9.2 \%$. The results were consistent with the literature. Distribution of infection agents according to infection type may differ among hospitals or countries. Pneumonias take the first place among ICU infections. The most frequent agents causing pneumonia at ICUs are $P$. aeruginosa, $S$. aureus, Enterobacteriaceae and Acinetobacter spp. ${ }^{[12]}$ In the study about adult medical ICUs carried out by National Nosocomial Infections Surveilance, pneumonia agent frequency rates were $21 \%$ for $P$. aeruginosa, $20 \%$ for $S$. aureus, 9\% for Enterobacter spp., 8\% for Klebsiella pneumoniae. ${ }^{[17]}$ In a study performed by Nag et al., ${ }^{[18]}$ among 39 pneumonia patients with microbiological analysis, $25.6 \%$ had $P$. aeruginosa and $17.9 \%$ had K. pneumonia. Recently, it has been reported that there is an increase in the frequency of Gram positive bacteriae, especially S. aureus, as pneumonia agent. In a study carried out by Gastmeier et al., ${ }^{[19]}$ when distribution of pathogens as pneumonia agent was evaluated, the most frequent ones were determined as S. aureus $(24.1 \%)$, P. aeruginosa $(16.8 \%)$, Klebsiella spp. (12.1\%). In our consultation evaluations, the most frequent agent at pneumonias was determined as Pseudomonas spp. (29.4\%). It was followed by Acinetobacter spp. (22.7\%), Staphylococcus spp. (16.2\%), Klebsiella spp. (11\%).

Clinical view of urinary tract infection are not generally serious, but mortality is high when secondary bacteremia develops. Urinary catheter has an important role in its pathogenesis. ${ }^{[20]}$ The most frequent agents are E. coli, Enterococci, fungi like Candida spp. and P. aeruginosa. ${ }^{[12,20]}$ In a study carried out by Richards et al., ${ }^{[21]}$ the agents with their frequencies were Candida spp. with $24.8 \%$, E. coli with $18.5 \%$, Enterococcus spp. with $14.3 \%$. In another study carried out by Parlak et al., ${ }^{[22]}$ the most frequent urinary tract infection agents were Candida spp. $(27.2 \%)$, E. coli $(27.2 \%)$ and Staphylococcus spp. (12.9\%). When our results were evaluated, Candida spp. took the first place with $35.8 \%$, followed by E. coli with $13.6 \%$ and Pseudomonas spp. with $11.9 \%$. All these results were consistent with the literature.

Blood stream infections are 2-7 times more frequent at ICUs than in the other hospital units. Its contribution to mortality changes between $27-35 \%$. The most common agent among BSIs is CNS group with a rate of $30 \%$. The other agents are S. aureus, Enterococus spp., fungi such as Candida spp. and Gram negative enteric bacteria. ${ }^{[23]}$ In the study about adult medical ICUs carried out by National Nosocomial Infections Surveilance, BSI agent frequency rates were reported as 36\% for CNS, 16\% for Enterecoccus spp. and $13 \%$ for S. aureus. ${ }^{[21]}$ In our consultation evalu- ations, Staphylococcus spp. (30.3\%) group was the most frequent among BSIs, followed by Enterococcus spp. $(16.8 \%)$ and Acinetobacter spp. (12.2\%). Frequency rates among Staphylococcus spp. were evaluated as $18.9 \%$ for methicillin-resistant coagulase-negative Staphylococcus, and $11.4 \%$ for S. aureus (Table 5).

In a study carried out by Erbay et al., ${ }^{[11]}$ among patients who were diagnosed with SSI, the most frequent infection agents were reported as MRSA, Acinetobacter spp. and CNS. In our study, the most frequent agents were Acinetobacter spp. (23.7\%), Pseudomonas spp. (16.3\%), Staphylococcus spp. (13.4\%) (Table 5). These results were similar to the previous results.

Nearly one-half of hospitalized patients receive antimicrobial agents, and antimicrobial usage varies widely across hospitals. Infection control committee should monitor the antimicrobial susceptibility profiles produced by the microbiology laboratory on a regular basis to observe for trends in the development of antimicrobial resistance. The primary administrative function of the infection control program is to develop, implement, and continually evaluate policies and procedures designed to minimize the risk of nosocomial infection. ${ }^{[1]}$

As a result, health-care related infections develop often at intensive care units. When the data of our country and of foreign countries are evaluated, it was revealed that the most common infection among ICU infections is pneumonia, and Gram negative bacteria is the first among the agents. By virtue of its control over hospital formularies and of the distribution of medications within the hospital, the hospital pharmacy is often in a position to contribute significantly to defining and directing the appropriate use of antibiotics. ${ }^{[24]}$ We believe that early determination of these infections and treatment with proper antibiotics according to the agent and resistance data with the help of Infectious Diseases consultations, will help decrease the frequency of infections caused especially by resistant microorganisms, with effective infection control precautions.

\section{REFERENCES}

1. Edmond MB, Wenzel RP. Organization for infection control. In: Mandell GL, Bennett JE, Dolin R, editors. Principles and practice of infectious diseases. 6th ed. New York: Elsevier Churchill Livingstone; 2005. p. 3323-6.

2. Esposito S, Leone S. Antimicrobial treatment for Intensive Care Unit (ICU) infections including the role of the infectious disease specialist. Int J Antimicrob Agents 2007;29:494-500.

3. Çetin ÇB, Turgut H, Kaleli İ, Yalçın AN, Orhan N. Pamukkale Üniversitesi Tıp Fakültesi Hastanesi yoğun bakım ünitesinde nozokomiyal infeksiyonlar. Hastane İnfeksiyonları Dergisi 2002;6.98-101.

4. Beşirbellioğlu BA. Dünyada ve Türkiye'de infeksiyon hastalıkları konsültasyonları. Klimik Dergisi 2005;18:91-3.

5. Eggimann P, Pittet D. Infection control in the ICU. Chest 2001;120:2059-93.

6. Schlesinger Y, Paltiel O, Yinnon AM. Analysis and impact 
of infectious disease consultations in a general hospital. J Hosp Infect 1998;40:39-46.

7. Petrak RM, Sexton DJ, Butera ML, Tenenbaum MJ, MacGregor MC, Schmidt ME, et al. The value of an infectious diseases specialist. Clin Infect Dis 2003;36:1013-7.

8. Yapar N, Erdenizmenli M, Oğuz VA, Kuruüzüm Z, Senger SS, Cakir N, et al. Infectious disease consultations and antibiotic usage in a Turkish university hospital. Int J Infect Dis 2006;10:61-5.

9. Akalin H, Kahveci F, Ozakin C, Helvaci S, Gedikoğlu S, Kutlay $\mathrm{O}$, et al. Influences of alternate therapy protocol and continuous infectious disease consultation on antibiotic susceptibility in ICU. Intensive Care Med 1999;25:1010-2.

10. Vincent JL, Bihari DJ, Suter PM, Bruining HA, White J, Nicolas-Chanoin $\mathrm{MH}$, et al. The prevalence of nosocomial infection in intensive care units in Europe. Results of the European Prevalence of Infection in Intensive Care (EPIC) Study. EPIC International Advisory Committee. JAMA 1995;274:639-44.

11. Erbay H, Yalcin AN, Serin S, Turgut H, Tomatir E, Cetin $\mathrm{B}$, et al. Nosocomial infections in intensive care unit in a Turkish university hospital: a 2-year survey. Intensive Care Med 2003;29:1482-8.

12. Strausbaugh LJ. Nosocomial respiratory infections. In: Mandell GE, Bennett JE, Dolin R, editors. Mandell, Douglas, and Bennett's principles and practice of infectious diseases. 6th ed. New York: Elsevier Churchill Livingstone; 2005. p. 3362-70.

13. Namıduru M, Karaoğlan İ, Göksu S, Dikensoy Ö, Karaoğlan M. Cerrahi yoğun bakım ünitesinde hastane infeksiyonu etkeni olan bakteriler ve antibiyotiklere direnç durumları. İnfeksiyon Dergisi 2003;17:39-44.

14. Palabıyıkoğlu İ, Tekeli E, Çokça F, Arıkan Akan Ö, Ünal N, Aysev D, et al. Ankara Üniversitesi Tıp Fakültesi hastaneleri yoğun bakım ünitelerinde hastane infeksiyonları sürveyansı: alet kullanım ve alet ilişkili infeksiyon oranları. Flora Dergisi 2006;11:89-95.
15. Eltahawy AT. Gram-negative bacilli isolated from patients in intensive care unit: prevalence and antibiotic susceptibility. J Chemother 1997;9:403-10.

16. Orrett FA. Nosocomial infections in an intensive care unit in a private hospital. West Indian Med J 2002;51:21-4.

17. Richards MJ, Edwards JR, Culver DH, Gaynes RP. Nosocomial infections in medical intensive care units in the United States. National Nosocomial Infections Surveillance System. Crit Care Med 1999;27:887-92.

18. Nag VL, Ayyagari A, Venkatesh V, Dash NR, Ghar M, Prasad KN. Bacterial isolates from mechanically ventilated patients with nosocomial pneumonia within intensive care unit of a tertiary care center. J Commun Dis 2005;37:281-7.

19. Gastmeier P, Geffers C, Sohr D, Schwab F, Behnke M, Rüden $\mathrm{H}$. Surveillance of nosocomial infections in intensive care units. Current data and interpretations. [Article in German] Wien Klin Wochenschr 2003;115:99-103.

20. Warren JW. Nosocomial urinary tract infections. In: Mandell GL, Bennett JE, Dolin R, editors. Mandell, Douglas, and Bennett's principles and practice of infectious diseases. 6th ed. New York: Elsevier Churchill Livingstone; 2005. p. 3370-81.

21. Richards MJ, Edwards JR, Culver DH, Gaynes RP. Nosocomial infections in combined medical-surgical intensive care units in the United States. Infect Control Hosp Epidemiol 2000;21:510-5.

22. Parlak E, Erol S, Kizilkaya M, Altoparlak U, Parlak M. Nosocomial urinary tract infections in the intensive care unit patients. [Article in Turkish] Mikrobiyol Bul 2007;41:39-49.

23. Suljagić V, Cobeljić M, Janković S, Mirović V, MarkovićDenić L, Romić P, et al. Nosocomial bloodstream infections in ICU and non-ICU patients. Am J Infect Control 2005;33:333-40.

24. Hopkins CC. Pharmacy service. In: Mayhall CG, editor. Hospital epidemiology and infection control. 3rd ed. Philadelphia: Lippincott Williams and Wilkins; 2004. p. 1315-22. 